\title{
Structure and Measurement of Basic Value: Validity Test of Multidimensional Constructions Schwartz Value Survey (SVS)
}

\author{
Sivia Febi Putri ${ }^{1}$, Natris Idriyani ${ }^{2}$ \\ ${ }^{1}$ Universität Hamburg, German \\ ${ }^{2}$ Faculty of Psychology, UIN Syarif Hidayatullah Jakarta, Indonesia \\ silviafebriputri@gmail.com
}

\begin{abstract}
Applying the main principles of life is important to support the daily life of transmigrant students. As explained by Rokeach (in Sauter, 1984), values are rules and principles which learned to help choose life alternatives, resolve conflicts and make decisions. Related to the concept of value, this study used the basic concepts of Schwartz (2005). The purpose of this research is to test the construct validity of the modified Schwartz Value Survey (SVS) measuring instrument by adjusting the conditions of research respondents. This instrument is used to measure the values of transmigrant students in living their lives and learning processes. Dimensions of this instrument are multidimensional. There are IO dimensions used in the basic value variable, namely self-direction, stimulation, hedonism, achievement, power, security, conformity, tradition, benevolence, and universalism with a total of 50 items. This study involved 25I participants, with an age range between I9-2I years. Participants in this study were active students of UIN SyarifHidayatullah Jakarta from outside the Greater Jakarta area (Jakarta, Bogor, Depok, Tangerang, Bekasi) who currently live in boarding houses, dormitories or rented houses. The factor analysis method used in this study is Confirmatory Factor Analysis (CFA) with a Lisrel 8.70 program. The test results prove that all subscales fit measure one factor and there are 50 valid items. And these results showed that all of aspect in basic value, which consists of 10 aspects that are multidimensional. CFA test results show that all $\mathrm{IO}$ aspects of basic value are fit with the data.
\end{abstract}

Keywords: construct validity; basic value; multidimensional Schwartz Value Survey; confirmatory factor analysis

\begin{abstract}
Abstrak
Untuk menjalani proses kehidupan dan belajar pada mahasiswa merantau, maka perlu hendaknya mengaplikasikan prinsip-prinsip utama yang ada di dalam diri. Rokeach (dalam Sauter, I984)menjelaskan bahwa value merupakan prinsip-prinsip yang dipelajari dan aturan untuk membantu memilih alternatif-alternatif yang ada, menyelesaikan konflik dan membuat keputusan. Terkait konsep tentang value, penelitian ini menggunakan konsep dasar dari Schwartz (2005). Tujuan adanya penelitian ini adalah untuk menguji validitas konstruk alat ukur Schwartz Value Survey (SVS) yang dimodifikasi dengan menyesuaikan kondisi responden penelitian. Instrumen ini digunakan untuk mengukur nilai-nilai yang dimiliki mahasiswa rantau dalam menjalani kehidupan dan proses belajar. Dimensi dalam alat ukur ini merupakan multidimensi. Adapun dimensi yang digunakan pada variabel basic value ini adalah sebanyak IO dimensi, yaitu self direction, stimulation, hedonism, achievement, power, security, comformity, tradition, benevolence, dan universalism dengan jumlah total aitem sebanyak 53 aitem. Penelitian ini melibatkan 251 partisipan, yakni sebanyak I23 (49\%) partisipan laki-laki dan I28 (51\%) partisipan perempuan, dengan rentang usia antara I9-2I tahun. Partisipan penelitian ini adalah mahasiswa aktif UIN Jakarta yang berasal dari luar daerah Jabodetabek, yang saat ini tinggal di kostan, asrama atau rumah kontrakan. Metode analisis faktor yang digunakan dalam penelitian ini adalah Confirmatory Factor Analysis (CFA) dengan program lisrel 8.70. Hasil pengujian membuktikan bahwa seluruh subskala fit (sesuai) mengukur model satu faktor dan terdapat 50 aitem yang valid. Hasil ini menunjukkan bahwa seluruh aspek dalam basic value yang terdiri dari IO aspek adalah multideimensional. Test CFA menghasilkan IO aspek basic value yang fit dengan data.
\end{abstract}

Kata kunci : Validitas Konstruk, basic value; multidimensional Schwartz Value Survey; confirmatory factor analysis 


\section{Introduction}

Types of variables used in psychology are constructs. These constructs or by other names are called the measured psychological attributes, many of which are latent variables. Latent variables are psychological constructs that cannot be observed, assessed or measured directly. Psychometric studies explained that to measure a latent variable operational, definitions of the construct or attribute to be measured are needed. According to Fox (2010), in making an operational definition it is necessary to apply several processes, including determining the dimensions, indicators, and arrangement of items from the construct or the measured attribute. Measurement aims to obtain scores that reflect the characteristics of individuals (Allen \& Yen, 1979). According to Anastasi\&Urbina (2004), a score can be obtained from the test participant's response to a question or statement that represents a construct. The obtained score on the measurement of a sample of behaviour will be evaluated and assessed by standard procedures as a reference to determine a decision.

The psychological variables in the form of constructs that will be measured in this study are basic personal values, hereinafter referred to as basic values. To live a good life, there are principles of life that need to be possessed by individuals - in this case, transmigrant students. Until now, basic values are an important feature to increase adversity quotient in individuals. Schwartz (2005) revealed that value is a belief that is primarily placed in a person's belief system, about how people should or shouldn't behave. Values are criteria used to evaluate actions, people and events (Schwartz, 2005). According to Schwartz (1994), values form the basis of one's choice of behaviour. Almost all forms of behaviour originate from values adopted by persons. Values can motivate, give direction, and emotional intensity to an action. Schwartz and Bardi (2003) also explained the same thing: a behaviour can consist of several values. According to him, the natural way to achieve values that are considered important is to behave in ways that express or enhance their achievements. For example, people pursue security value by acting in ways that enhance their safety, and they pursue hedonism value by engaging in fun activities.

Borualogo (20I4) also stated that the values proposed by Schwartz (1992) had a significant influence on the resilience of Batak, Minang and Sundanese ethnic migrants in Bandung. Where firmness (resilience) is one of the building theories of adversity quotient (Stoltz, 2000). This shows that the values adopted by individuals - which in this case are trans-migrant students - can have an impact on the creation of a positive and conducive condition in life. Transmigrant students can develop and achieve the main goal of migrating, namely success.

To measure the variation of basic values possessed by transmigrant students, a valid measurement tool is certainly needed. The validity of a measuring instrument becomes the main requirement for the realization of a good measuring instrument. In this study, confirmatory analysis factors of the basic value dimensions will be carried out. This research is also interesting to do because there are quite many transmigrant students from various regions and cultures in every university, especially UIN Syarif Hidayatullah Jakarta. Thus, it is necessary to have a measuring tool that measures the basic values possessed by these transmigrant students.

\section{Literature Review}

Value has been conceptualized by many experts. Rokeach (in Sauter, 1984) explained that everyone organizes values into a value system that has a definition as an organization that is learned from principles and rules to help choose one of the alternatives, resolve conflicts, and make decisions.

Schwartz and Savig (1995) defined value as something that creates desires, changing goals depending on the situation, variations, goals or interests that function as principles in human life (Cohen \& Liu 20I0). Value also refers to the importance of an object for individuals. Something has value if it has meaning or 
significance to someone. Williams and Kluckhohn also see value as a criterion used to evaluate actions, people and events (in Schwartz, 2005).

Schwartz (1992, 2005) also defined values in his theory, Theory of Basic Human Values, into a coherent system that underlies and can help explain the process of individual decision making, attitudes, and behaviour. This coherent structure comes from the social environment and psychological conflict or compatibility between values based on individual experiences when they make decisions into everyday life. In his theory, Schwartz called the values that exist in a person as basic values (in Schwartz et al. 2012).

Schwartz's definition of value has been used in recent studies such as in research: Ros, Schwartz, and Surkiss (1999); Spini (2003); Nosse and Sagiv (2005); and Grunert and Juhl (2015). This study also used the definition of Schwartz (I992, 20I2), namely value as (I) a belief, (2) motivate action, (3) beyond a specific situation, (4) acting as a standard or criterion, (5) arranged based on the degree of importance.Schwartz arranged 10 types of values, each of which has motivational differences and originates from individual personal needs (Schwartz, 2012). The ten values including the following:

\section{Self-Direction}

This value is derived from the organism's need for control and mastery of knowledge. The motivational purpose of this value is to think and act freely, create and explore. Values covered by self-direction are creativity, freedom, self-determination, curiosity, and independence.

2. Stimulation

This type of value comes from an individual's need for variety and stimulation to keep one's activities optimal. The motivational goals of this type are excitement, something new and challenges in life. The values encompassed are varied lives, exciting and courageous lives.

3. Hedonism (Hedonism)

This type is sourced from the human need for enjoyment obtained through the fulfilment of needs. This type of motivational goal is pleasure and satisfaction for oneself. Value covered is enjoyment.

4. Achievement

This type of motivational goal is a personal success by pointing to competencies that are in accordance with social standards. Success becomes a necessity if someone feels the need to develop themselves and also the demands of the community. Values in this type are successful and capable.

5. Power

This value is a transformation of the individual's need to dominate and control others who are identified through the analysis of social motives. The aim is to gain social status, prestige, and control or domination over others and resources. Values covered are authority, wealth, social power, social recognition, and maintaining self-image in society.

6. Security

This value comes from the basic needs of individuals and groups, with motivational goals of security, harmony, and stability from the community, from a relationship and self. The values covered are cleanliness, social order, reciprocation, family security, national security, ownership, and health.

7. Conformity

This value comes from the need for interaction and function in a group that works well. The motivational goal is to limit actions, impulses that may interfere with others or are not in line with social norms. Values are obedient, disciplined, polite, and respectful to parents and elders.

8. Tradition

Tradition is a symbol of group solidarity, a unique manifestation of worth, and is a guarantee of the continuity of the group. Tradition comes in the form of religious rituals of beliefs and norms of behaviour. The motivational goals of this type are appreciation, commitment, and respect for customs 
which the individual emphasizes by his/her culture. Values that are included are the appreciation of tradition, fate acceptance, being modest, detached and moderate.

9. Benevolence

The purpose of this motivational value is to maintain and improve the welfare of others who have good relations with individuals. This value comes from the need for positive interaction to develop groups and the organismic need for affiliation. The values covered are helpful, loyal, forgiving, honest, true friendship, responsible, and mature love.

I0. Universalism (Universalism)

This type is included in the values of maturity and prosocial actions. The motivational goals are understanding, appreciation, tolerance, and protection of the welfare of others and nature. This value comes from the need for survival for groups and or individuals, accepting the differences of others and protecting the natural environment. The values covered are protecting the environment, integrating with nature, a beautiful world, social justice, wide view, wisdom, equality, and a peaceful world.

Previous studies conducted by previous researchers on basic values, in general, use the Schwartz Value Survey (SVS). The instrument used to measure basic values variables is the Schwartz Value Survey (SVS) created and developed by Schwartz, (1992, 2006). SVS has been tested on 60,000 people in 64 countries and has been translated into 47 languages, hence it has good reliability of 0.70 - 0.90 (Nosse\&Sagiv, 2005). When filling out SVS, there are nine choices of answers, ranging from 'very important' which are labelled 7 to 'very contrary to me' which are labelled -I.

In addition to the Schwartz Value Survey (SVS), there are other measuring tools to measure basic values, namely the Potential Value Questionnaire (PVQ) which is an alternative measurement tool for the development of the Schwartz Value Survey (SVS). The PVQ measurement tool is used for children aged II to I4 years and for adults who do not receive the education as appropriate (Schwartz, 20I2). The researcher used the Schwartz Value Survey (SVS) as an instrument measurement with consideration of this study sample are students. The Schwartz Value Survey (SVS) is widely used in recent studies such as in research: Ros, Schwartz, and Surkiss (1998); Spini (2003); Nosse and Sagiv (2005); Grunert (2015); and Fischer and Schwartz (2015). But in this study, researcher used a modified SVS because the results of the pilot study showed invalid results. In addition, researcher also added one item in the hedonism dimension because on the original scale the hedonism dimension only had 3 items, hence, the SVS in this study consisted of 53 items with the choice of answers Very Appropriate, Appropriate, Unsuitable and Very Inappropriate.

\section{Method}

\section{Design and Samples}

This research is a non-experimental research design with a quantitative approach. Therefore, this study did not manipulate the variables and did not give any treatment to the participants of this study, hence the data obtained from participants were based on ex post facto (Simon \& Goes, 20I3). The target population in this study is transmigrant students in UIN SyarifHidayatullah Jakarta. The characteristics of the population in this study are active students who are pursuing undergraduate education at UIN SyarifHidayatullah Jakarta, amounting to 22.247 people (Academic UIN Jakarta, 20I4), coming from outside JABODETABEK area (Jakarta, Bogor, Tangerang, Bekasi), and living in boarding houses, dormitories or rented houses.

The sample size in this study is based on a formula made by Roscoe (Sugiyono, 20II) which is I0 times the number of research variables. The variables in this study were I5 thus, the minimum number of samples was I50. Researchers managed to collect data from 25I respondents, which means the number of samples in this study had been more than the minimum amount. The sampling technique in this study uses nonprobability sampling, that is, the possibility of being selected from each respondent member of the population 
is unknown. The sampling method used was purposive sampling. This technique was chosen with consideration of the suitability of the aims and objectives of the study with the sampling criteria described above.

\section{Measuring instrument}

The measuring instrument used to measure basic values is the Schwartz Value Survey (SVS) which has been developed and revised by researchers, Shalom H. Schwartz (Schwartz, et al., 2012). At first the researchers conducted a pilot study using Schwartz Value Survey (SVS) measurement tools. However, the results obtained show that Schwartz Value Survey (SVS) items are invalid so the researcher modifies the measuring instrument based on the dimensions of basic values that have been developed by Schwartz (2012).

The Schwartz theory of basic values identifies "ten basic personal values that are recognized across cultures and explains where they come from." They are:

I. "Self-Direction - Defining goal: independent thought and action-choosing, creating, exploring."

2. "Stimulation - Defining goal: excitement, novelty, and challenge in life."

3. "Hedonism - Defining goal: pleasure or sensuous gratification for oneself."

4. "Achievement - Defining goal: personal success through demonstrating competence according to social standards."

5. "Power - Defining goal: social status and prestige, control or dominance over people and resources."

6. "Security - Defining goal: safety, harmony, and stability of society, of relationships, and of self."

7. "Conformity - Defining goal: restraint of actions, inclinations, and impulses likely to upset or harm others and violate social expectations or norms."

8. "Tradition - Defining goal: respect, commitment, and acceptance of the customs and ideas that one's culture or religion provides."

9. "Benevolence - Defining goal: preserving and enhancing the welfare of those with whom one is in frequent personal contact (the 'in-group')."

I0. "Universalism - Defining goal: understanding, appreciation, tolerance, and protection for the welfare of all people and for nature."

The Schwartz Value Survey (SVS) questionnaire items refer to the description of the IO basic values definitions above. The items used in this study have been modified, which consists of 53 items that represent the dimensions of basic values, namely self-direction, stimulation, hedonism, achievement, power, security, comformity, tradition, benevolence, universalism. The division of items for each dimension can be seen in table I.

Table I. Blue print basic values scale

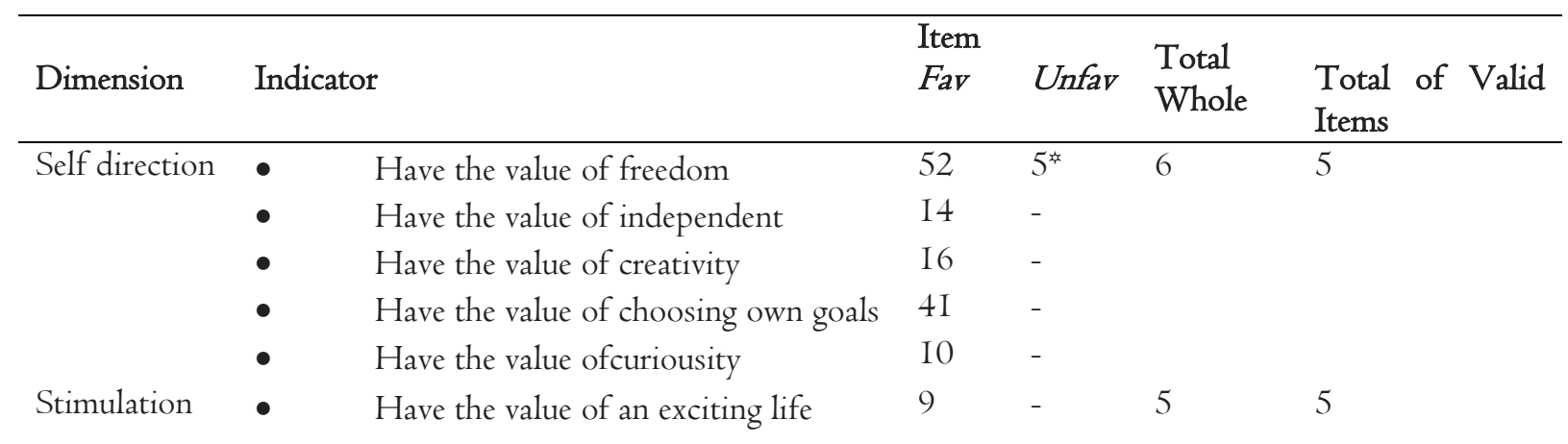




\begin{tabular}{|c|c|c|c|c|c|}
\hline \multirow[t]{3}{*}{ Dimension } & Indicator & \multirow{2}{*}{$\begin{array}{l}\text { Item } \\
\text { Fav } \\
25\end{array}$} & \multirow{3}{*}{$\begin{array}{l}\text { Unfav } \\
- \\
47\end{array}$} & \multirow[t]{3}{*}{$\begin{array}{l}\text { Total } \\
\text { Whole }\end{array}$} & \multirow[t]{3}{*}{$\begin{array}{l}\text { Total of Valid } \\
\text { Items }\end{array}$} \\
\hline & Have the value of novelty & & & & \\
\hline & Have the value of daring & 3,37 & & & \\
\hline \multirow[t]{2}{*}{ Hedonism } & Have the value of pleasure & 4,6 & 24 & 5 & 5 \\
\hline & Have the value of enjoying life & 48 & $3 \mathrm{I}$ & & \\
\hline \multirow[t]{4}{*}{ Achievement } & Have the value of capable & $\begin{array}{l}34,4 \\
3\end{array}$ & - & 5 & 5 \\
\hline & Have the value of successful & 26 & - & & \\
\hline & Have the value of influential & 39 & - & & \\
\hline & Have the value of ambitious & 19 & - & & \\
\hline \multirow[t]{5}{*}{ Power } & Have the value of social recognition & 12 & - & 5 & 4 \\
\hline & Have the value of social power & 23 & - & & \\
\hline & Have the value of authority & 27 & - & & \\
\hline & $\begin{array}{l}\text { - Have the value of preserving my } \\
\text { public image }\end{array}$ & 42 & - & & \\
\hline & - Have the value of wealth & 49 *⿻ & - & & \\
\hline \multirow[t]{5}{*}{ Security } & $\begin{array}{l}\text { - Have the value of reciprocation } \\
\text { offavors }\end{array}$ & - & 7 & 6 & 6 \\
\hline & - $\quad$ Have the value of social order & - & 8 & & \\
\hline & Have the value of national security & 13 & - & & \\
\hline & Have the value of family security & $\begin{array}{l}22,5 \\
3\end{array}$ & - & & \\
\hline & Have the value of sense of belonging & - & $2 \mathrm{I}$ & & \\
\hline \multirow[t]{4}{*}{ Conformity } & Have the value of self discipline & 18 & 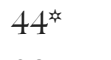 & 5 & 4 \\
\hline & Have the value of politeness & - & 32 & & \\
\hline & $\begin{array}{l}\text { Have the value of honoring parents } \\
\text { and elders }\end{array}$ & 36 & - & & \\
\hline & - $\quad$ Have the value of obedient & - & I7 & & \\
\hline \multirow[t]{5}{*}{ Tradition } & Have the value of humble & II & - & 6 & 6 \\
\hline & Have the value of moderate & 20 & - & & \\
\hline & $\begin{array}{l}\text { - Have the value of accepting my } \\
\text { portion in life }\end{array}$ & - & 40 & & \\
\hline & - $\quad$ Have the value of devout & $\begin{array}{l}46,5 \\
I\end{array}$ & - & & \\
\hline & $\begin{array}{l}\text { - Have the value of respect for } \\
\text { tradition }\end{array}$ & 50 & - & & \\
\hline \multirow[t]{5}{*}{ Benevolence } & Have the value ofresponsible & - & 28 & 5 & 5 \\
\hline & Have the value of loyal & 33 & - & & \\
\hline & Have the value of honest & 45 & - & & \\
\hline & Have the value of helpful & - & 29 & & \\
\hline & Have the value of forgiving & I5 & - & & \\
\hline \multirow[t]{5}{*}{ Universalism } & Have the value of equality & $\mathrm{I}$ & - & 5 & 5 \\
\hline & Have the value of social justice & - & 2 & & \\
\hline & Have the value of world of beauty & 30 & - & & \\
\hline & Have the value of broad minded & - & 35 & & \\
\hline & $\begin{array}{l}\text { - Have the value of protecting the } \\
\text { environment }\end{array}$ & - & 38 & & \\
\hline Total & & 37 & I6 & 53 & 50 \\
\hline
\end{tabular}




\section{Data analysis}

In this study, the construct validity test of the Schwartz Value Survey (SVS) was tested by Confirmatory Factor Analysis (CFA) with the Lisrel program, 8.70. CFA is a statistical technique used to test relationships between latent constructs (such as attitude, trait, intelligence, and basic value).

As mentioned by Brown (2006) that both EFA (Exploratory Factor Analysis) and Confirmatory Factor Analysis (CFA) actually aim to determine the relationship between indicators and latent variables. But basically there are differences in the number and nature of specifications and restrictions based on theory and data created by the factor model. In the CFA process the researcher determines the number of factors and the measurement model on the factor. Unlike EFA, CFA requires a strong empirical or conceptual basis to determine the specification and evaluation of factor models. The Confirmatory Factor Analysis (CFA) explicitly tests a hypothesis regarding the relationship of observed variables with latent or construct variables, (Jakson, Purc-Stephenson \&Gillaspy, 2009).

Each variable in this study will be tested for construct validity using Confirmatory Factor Analysis (CFA). The logic of the CFA according to Umar (20I2), namely: I) That there is a concept or trait that is operationally defined so that questions or statements can be drawn up to measure it. This trait is called a factor, while the measurement of this factor is done through an analysis of the responses to these items; 2. Theorized that each item only measures one factor, and the subscale only measures one factor as well. This means that both the item and subscale are unidimensional; 3 )The statement was tested with Chi-Square. If the Chi-Square results are not significant ( $\mathrm{p}>0.05)$, then the hypothesis is "rejected". This means that the unidimensionality theory is acceptable that items only measure one factor. But if Chi-Square is significant ( $p$ $<0.05$ ), a modification is done by releasing parameters in the form of correlation of measurement error. This happens when an item measures other than the construct that it wants to measure. This means that the item in addition to measuring what is to be measured also measures other things (measuring more than one construct / model / multidimensional). After some measurement errors are freed to be correlated, then a fit model will be obtained, then this final model will be used in the next step; 4) If the model is fit, then the next step is to analyze the item by seeing whether the factor load of the item is significant and has a positive coefficient. The criteria for eliminating or dropping items are as follows: I) Test whether an item is significant or not in measuring the thing to be measured, using t-test. In this case what is tested is the factor load coefficient for each item. If the value of $\mathrm{T}$ factor load coefficient ( $\mathrm{t}>\mathrm{I}$.96) then the item is declared significant in measuring the construct to be measured. This means that the item is not dropped. While items whose $t$ value is not significant ( $t<1.96)$, the items will be dropped; 2) If an item has a negative coefficient, then the item will be dropped because it measures the opposite of what it wants to be measured. However, if an item consists of statements that are unfavorable then of course the factor load coefficient will be negative. Therefore, in items such as this the score must be reversed first before the factor analysis and factor score calculation is carried out in order to obtain a positive factor load coefficient. If the score on the item has been reversed but produces a coefficient that is negative then the item is dropped; 3) If the measurement error of the items is too much correlated with each other, then the item should be dropped. Because such items besides measuring what they want to be measured, also measure other things (multidimensional). Then the items used are only valid items.

After the fit model is obtained, the score factor is calculated. The use of this score factor is to avoid biased research results as a result of measurement errors. So the score analyzed in this study is not the score obtained from the variables in general, but rather the true score obtained by calculating the difference in validity of each item. However, to avoid the negative and positive (Z-score) score factor, the researcher transforms the factor into a $\mathrm{T}$-score with the formula, namely: $\mathrm{T}$-score $=50+(\mathrm{I} 0 \mathrm{x}$ score factor $)$.

Related to this, the $\mathrm{T}$-score will have a mean $=50$ and $\mathrm{SD}=\mathrm{IO}$ and it is expected that all scores are positive numbers that have an estimated range of between 0 and I00. After obtaining a score factor that has been changed to $\mathrm{T}$-score, this standard value will be analyzed in the hypothesis and correlation regression test. 


\section{Results and Discussion}

\section{Results}

\section{Test the validity of the self-direction measuring instrument}

The researcher tested the construct validity of the self direction variable using the CFA first order model. In this study, the construct of the self-direction variable is unidimensional. The initial results of the CFA analysis were not fit with Chi-Square $=21.69, \mathrm{df}=9$, P-Value $=0.00993$, and RMSEA $=0.075$. But after making modifications once, the fit model with Chi-Square $=$ I2.9I, $\mathrm{df}=8$, P-Value $=0.1 \mathrm{I} 488$, and RMSEA $=0.050$.

The next step is to see whether or not the item is significant by looking at the $\mathrm{T}$-value. If the $\mathrm{T}$-value $>$ I.96 means that the item is significant and vice versa. The results show that item 5 has a T-value $<$ I.96 and the factor load coefficient value for the other five items is minus (-), then item 5 must be dropped. Next, the researcher re-tested CFA by not including item 5. The results showed Chi-Square $=I 4.98, \mathrm{df}=5, \mathrm{P}-\mathrm{V}$ alue $=$ 0.01043 , and RMSEA $=0.089$. With a P-Value of $0.01043(<0.05)$ which means that this model is not yet fit. Then the researchers made modifications to this model, namely by freeing each item to correlate. After one modification, the Chi-Square value $=6.87, \mathrm{df}=4, \mathrm{P}-$ Value $=0.14287$, and RMSEA $=0.054$. With a PValue $>0.05$ it means that this model is fit. Thus the items in this self direction variable only measure one factor, namely self direction. The factor load coefficient for the self direction measurement item is presented in table 2:

Table 2. Loading Factor of Self direction

\begin{tabular}{lllll}
\hline Item & Coefficient & Standard Error & T-value & Significant \\
\hline I0 & $0.7 \mathrm{I}$ & 0.06 & $\mathrm{II} .56$ & $\sqrt{ }$ \\
I4 & 0.69 & 0.06 & 10.78 & $\sqrt{ }$ \\
I6 & 0.74 & 0.06 & 12.28 & $\sqrt{ }$ \\
$4 \mathrm{I}$ & 0.53 & 0.06 & 8.10 & $\sqrt{ }$ \\
52 & 0.58 & 0.07 & 8.63 & $\sqrt{ }$ \\
\hline
\end{tabular}

Note: the sign $\sqrt{ }=$ significant ( $\mathrm{t}>$ I.96); $\mathrm{X}=$ not significant

Based on table 2 it can be seen that all items are significant ( $>$ I.96) and all coefficients are positively charged. This means that the five items in the self-direction measuring instrument prove to be significant and will not be dropped, and can be included in the analysis of the hypothesis test.

\section{Test the validity of the stimulation measuring instrument}

The researcher tested the construct validity of the stimulation variable with the CFA first order model. In this study, the construct of variable stimulation is unidimensional. The calculation of the CFA data for the one factor model of this variable obtained the initial calculation score Chi-Square $=54.44, \mathrm{df}=5$, P-Value $=$ 0.00000 , and RMSEA $=0.199$. With a P-Value of $0.00000(<0.05)$ which means that this model is not yet fit. Then the researchers made modifications to this model, namely by freeing each item to correlate. After doing two modifications, the Chi-Square value $=\mathrm{I} .36 \mathrm{df}=3, \mathrm{P}-$ Value $=0.71534$, and RMSEA $=0.000$. With a P-Value $>0.05$ it means that this model is fit. Thus the items in this stimulation variable only measure one factor, namely stimulation.

The next step is to look at whether or not the item is significant in measuring what is being measured, as well as determining whether a particular item needs to be dropped or not. In this case, what is tested is the factor load coefficient of the item. The test is done by looking at the T-value for each factor load coefficient, if the value of $\mathrm{t}>\mathrm{I} .96$ means that the item is significant and vice versa. The factor load coefficient for stimulation measurement items is presented in table 3. 
Table 3. Loading Factor of Stimulation

\begin{tabular}{lllll}
\hline Item & Coefficient & Standard Error & T value & Significant \\
\hline 3 & & & & \\
9 & 0.55 & 0.07 & 8.00 & $\sqrt{ }$ \\
25 & 0.85 & 0.07 & II.44 & $\sqrt{ }$ \\
37 & 0.66 & 0.07 & 9.37 & $\sqrt{ }$ \\
47 & 0.35 & 0.07 & 4.95 & $\sqrt{ }$ \\
\hline
\end{tabular}

Note: the sign $\sqrt{=}$ significant $(t>1.96) ; X=$ not significant

Based on table 3 it can be seen that all items are significant ( $>$ I.96) and all coefficients are positively charged. This means that the five items in the stimulation gauge are proven to be significant and will not be dropped, and can be included in the analysis of the hypothesis test.

\section{Test the validity of hedonism measuring instrument}

In the construct validity test of hedonism variables, researchers conducted a validity test with the CFA first order model. In this study, the construct of the hedonism variable is unidimensional. The calculation of the CFA data for the one factor model of this variable obtained the initial calculation score Chi-Square $=28.89$, $\mathrm{df}=5$, P-Value $=0.00002$, and RMSEA $=0.138$. With a P-Value $0.00002(<0.05)$ which means that this model is not yet fit. Then the researchers made modifications to this model, namely by freeing each item to correlate. After doing two modifications, the Chi-Square value $=1.74, \mathrm{df}=3, \mathrm{P}-\mathrm{V}$ alue $=0.628 \mathrm{I} 5$, and RMSEA $=0.000$. With a P-Value $>0.05$ it means that this model is fit. Thus the items in this hedonism variable only measure one factor, namely hedonism.

The next step is to look at whether or not the item is significant in measuring what is being measured, as well as determining whether a particular item needs to be dropped or not. In this case, what is tested is the factor load coefficient of the item. The test is done by looking at the T-value for each factor load coefficient, if the T-value > I.96 means that the item is significant and vice versa. The factor load coefficient for hedonism measurement items is presented in table 4.

Table 4. Loading Factor of Hedonism

\begin{tabular}{lllll}
\hline Item & Coefficient & Standard Error & T value & Significant \\
\hline 4 & 0.34 & 0.07 & $5.1 \mathrm{I}$ & $\sqrt{ }$ \\
6 & 0.92 & 0.12 & 7.92 & $\sqrt{ }$ \\
24 & 0.46 & 0.08 & 6.09 & $\sqrt{ }$ \\
$3 \mathrm{I}$ & 0.93 & 0.12 & 8.10 & $\sqrt{ }$ \\
48 & 0.43 & 0.07 & 5.86 & $\sqrt{ }$ \\
\hline
\end{tabular}

Note: the sign $\sqrt{ }=$ significant ( $\mathrm{t}>$ I.96); $\mathrm{X}=$ not significant

Based on table 4, it can be seen that all items are significant ( $>$ I.96) and all coefficients are positively charged. This means that the five items in the hedonism measuring instrument prove to be significant and will not be dropped, and can be included in the analysis of the hypothesis test.

\section{Test the validity of achievement measuring instrument}

In the test of construct validity of the achievement variable, researchers conducted a validity test with the CFA first order model. In this study, the construct of the achievement variable is unidimensional. Calculation of the CFA data for the one factor model of this variable obtained the initial calculation score Chi-Square $=$ 2I.09, $\mathrm{df}=5$, P-Value $=0.00078$, and RMSEA $=0.113$. With a P-Value of $0.00078(<0.05)$ which means that this model is not yet fit. Then the researchers made modifications to this model, namely by freeing each item to correlate. After one modification, the Chi-Square value $=7.38, \mathrm{df}=4, \mathrm{P}-$ Value $=0.1 \mathrm{I} 72 \mathrm{I}$, and 
RMSEA $=0.058$. With a P-Value $>0.05$ it means that this model is fit. Thus the items in this achievement variable only measure one factor, namely achievement.

The next step is to look at whether or not the item is significant in measuring what is being measured, as well as determining whether a particular item needs to be dropped or not. In this case, what is tested is the factor load coefficient of the item. The test is done by looking at the T-value for each factor load coefficient, if the T-value $>$ I.96 means that the item is significant and vice versa. The factor load coefficient for achievement measurement items is presented in table 5.

Table 5. Loading Factor of Achievement

\begin{tabular}{lllll}
\hline Item & Coefficient & Standard Error & T value & Significant \\
\hline I9 & 0.67 & 0.07 & 9.30 & $\sqrt{ }$ \\
26 & 0.76 & 0.07 & 10.35 & $\sqrt{ }$ \\
34 & 0.52 & 0.07 & 6.99 & $\sqrt{ }$ \\
39 & 0.47 & 0.07 & 6.67 & $\sqrt{ }$ \\
43 & $0.4 \mathrm{I}$ & 0.07 & 5.82 & $\sqrt{ }$ \\
\hline
\end{tabular}

Note: the sign $\sqrt{=}$ significant $(\mathrm{t}>\mathrm{I} .96) ; \mathrm{X}=$ not significant

Based on table 5, it can be seen that all items are significant ( $>$ I.96) and all coefficients are positively charged. This means that the five items in the performance measuring instrument prove to be significant and will not be dropped, and can be included in the analysis of the hypothesis test.

\section{Test the validity of the power measuring instrument}

In the test of construct validity of the power variable, researchers conducted validity testing with the CFA first order model. In this study, the construct of the power variable is unidimensional. Calculation of the CFA data for the one factor model of this variable obtained the initial calculation score Chi-Square $=22.26$, $\mathrm{df}=$ 5, P-Value $=0.00047$ and RMSEA $=0.118$. With a P-Value of $0.00047(<0.05)$ which means that this model is not yet fit. Then the researchers made modifications to this model, namely by freeing each item to correlate. After one modification, the Chi-Square value $=7.2 \mathrm{I}, \mathrm{df}=4$, P-Value $=0.125 \mathrm{I}$, and RMSEA $=$ 0.057. With a P-Value $>0.05$ it means that this model is fit. Thus the items in this power variable only measure one factor, namely power.

The next step is to look at whether or not the item is significant in measuring what is being measured, as well as determining whether a particular item needs to be dropped or not. In this case, what is tested is the factor load coefficient of the item. The test is done by looking at the T-value for each factor load coefficient, if the T-value $>1.96$ means that the item is significant and vice versa. The factor load coefficient for power measurement items is presented in table 6.

Table 6. Loading Factor of Power

\begin{tabular}{lllll}
\hline Item & Coefficient & Standard Error & T value & Significant \\
\hline I2 & 0.37 & 0.13 & 2.90 & $\sqrt{ }$ \\
23 & 0.36 & 0.09 & 4.10 & $\sqrt{ }$ \\
27 & 0.43 & 0.10 & 4.46 & $\sqrt{ }$ \\
42 & 0.78 & 0.15 & 5.10 & $\sqrt{ }$ \\
49 & 0.10 & 0.07 & 1.46 & $\mathrm{X}$ \\
\hline
\end{tabular}

Note: the sign $\sqrt{ }=$ significant $(\mathrm{t}>$ I.96); $\mathrm{X}=$ not significant

Based on table 6, it can be seen that there are significant and insignificant items. Significant items will not be dropped and are included in the hypothesis test analysis. While item number 5 proved to be insignificant and had to be dropped. So, it can be concluded that from the power measuring instrument there are 4 items that are significant and I item that is not significant. 


\section{Test the validity of security measuring instrument}

In the test of construct validity of security variables, researchers conduct validity tests with the CFA first order model. In this study, the construct of the security variable is unidimensional. The calculation of the CFA data for the one factor model of this variable obtained the initial calculation score Chi-Square $=6 \mathrm{I}$. I4, $\mathrm{df}=$ 9, $\mathrm{P}-$ Value $=0.00000$, and RMSEA $=0.152$. With a P-Value of $0.00000(<0.05)$ which means that this model is not yet fit. Then the researchers made modifications to this model, namely by freeing each item to correlate. After four modifications, the Chi-Square $=7.02, \mathrm{df}=5, \mathrm{P}-$ Value $=0.21939$, and RMSEA $=$ 0.040. With a P-Value $>0.05$ it means that this model is fit. Thus the items in this security variable only measure one factor, namely security.

The next step is to look at whether or not the item is significant in measuring what is being measured, as well as determining whether a particular item needs to be dropped or not. In this case, what is tested is the factor load coefficient of the item. The test is done by looking at the T-value for each factor load coefficient, if the T-value $>$ I.96 means that the item is significant and vice versa. The factor load coefficient for security measurement items is presented in table 7.

Table 7. Loading Factor of Security

\begin{tabular}{lllll}
\hline Item & Coefficient & Standard Error & T-value & Significant \\
\hline 7 & 0.48 & 0.09 & $5.3 \mathrm{I}$ & $\sqrt{ }$ \\
8 & 0.27 & 0.09 & 3.07 & $\sqrt{ }$ \\
$\mathrm{I3}$ & 0.40 & 0.08 & 4.74 & $\sqrt{ }$ \\
$2 \mathrm{I}$ & 0.32 & 0.09 & 3.78 & $\sqrt{ }$ \\
22 & 0.60 & $0.1 \mathrm{I}$ & 5.30 & $\sqrt{ }$ \\
53 & 0.67 & 0.12 & 5.79 & $\sqrt{ }$ \\
\hline
\end{tabular}

Note: the sign $\sqrt{ }=$ significant ( $\mathrm{t}>$ I.96); $\mathrm{X}=$ not significant

Based on table 7 , it can be seen that all items are significant ( $>$ I.96) and all coefficients are positively charged. This means that the six items in the security measuring instrument prove to be significant and will not be dropped, and can be included in the analysis of the hypothesis test.

\section{Test the validity of conformity measuring instrument}

In the construct validity test of conformity variables, the researcher conducts the validity test with the CFA first order model. In this study, the construct of the conformity variable is unidimensional. The calculation of the CFA data for the one factor model of this variable obtained the initial calculation score Chi-Square $=$ 3I.45, $\mathrm{df}=5$, P-Value $=0.0000 \mathrm{I}$, and RMSEA $=0.145$. With a P-Value 0.0000I $(<0.05)$ which means that this model is not yet fit. Then the researchers made modifications to this model, namely by freeing each item to correlate. After doing two modifications, the Chi-Square value $=2.60 \mathrm{df}=3$, P-Value $=0.45704$, and RMSEA $=0.000$. With a P-Value $>0.05$ it means that this model is fit. Thus the items in this conformity variable only measure one factor, namely conformity.

The next step is to look at whether or not the item is significant in measuring what is being measured, as well as determining whether a particular item needs to be dropped or not. In this case, what is tested is the factor load coefficient of the item. The test is done by looking at the T-value for each factor load coefficient, if the T-value $>1.96$ means that the item is significant and vice versa. The factor load coefficient for conformity measurement items is presented in table 8. 
Table 8. Loading Factor of Conformity

\begin{tabular}{lllll}
\hline Item & Coefficient & Standard Error & T-value & Significant \\
\hline I7 & 0.57 & 0.08 & 7.46 & $\sqrt{ }$ \\
I8 & 0.40 & 0.08 & 5.26 & $\sqrt{ }$ \\
32 & 0.60 & 0.08 & 7.82 & $\sqrt{ }$ \\
36 & 0.62 & 0.08 & 8.14 & $\sqrt{ }$ \\
44 & 0.03 & 0.09 & 0.36 & $\mathrm{X}$ \\
\hline
\end{tabular}

Note: the sign $\sqrt{ }=$ significant ( $\mathrm{t}>$ I.96); $\mathrm{X}=$ not significant

Based on table 8, it can be seen that there are significant and insignificant items. Significant items will not be dropped and are included in the hypothesis test analysis. While item number 5 proved to be insignificant and had to be dropped. So, it can be concluded that from the conformity measuring instrument there are 4 significant items and I non-significant item.

\section{Test the validity of tradition measuring instruments}

In the test of construct validity of tradition variables, researchers conducted validity tests with the CFA first order model. In this study, the construct of tradition variables is unidimensional. Calculation of the CFA data for the one factor model of this variable obtained the initial calculation score Chi-Square $=28.75$, $\mathrm{df}=$ 9, P-Value $=0.0007 \mathrm{I}$, and RMSEA $=0.094$. With a P-Value of 0.0007I $(<0.05)$ which means that this model is not yet fit. Then the researchers made modifications to this model, namely by freeing each item to correlate. After doing two modifications, the Chi-Square value $=8.9 \mathrm{I}, \mathrm{df}=7$, P-Value $=0.259 \mathrm{I} 4$, and RMSEA $=0.033$. With a P-Value $>0.05$ it means that this model is fit. Thus the items in this tradition variable only measure one factor, namely tradition.

The next step is to look at whether or not the item is significant in measuring what is being measured, as well as determining whether a particular item needs to be dropped or not. In this case, what is tested is the factor load coefficient of the item. The test is done by looking at the T-value for each factor load coefficient, if the T-value > I.96 means that the item is significant and vice versa. The factor load coefficient for tradition measurement items is presented in table 9.

Table 9. Loading Factor of Tradition

\begin{tabular}{lllll}
\hline Item & Coefficient & Standard Error & T-value & Significant \\
\hline II & 0.50 & 0.07 & 7.95 & $\sqrt{ }$ \\
20 & 0.55 & 0.07 & 6.25 & $\sqrt{ }$ \\
40 & 0.31 & 0.07 & 5.01 & $\sqrt{ }$ \\
46 & 0.66 & 0.07 & 5.64 & $\sqrt{ }$ \\
$5 \mathrm{I}$ & 0.77 & 0.07 & 4.92 & $\sqrt{ }$ \\
50 & 0.37 & 0.07 & 5.27 & \\
\hline
\end{tabular}

Note: the sign $\sqrt{ }=$ significant ( $\mathrm{t}>$ I.96); $\mathrm{X}=$ not significant

Based on table 9, it can be seen that all items are significant ( $t>1.96)$ and all coefficients are positively charged. This means that the six items in the tradition measuring instrument prove to be significant and will not be dropped, and can be included in the analysis of the hypothesis test.

\section{Test the validity of benevolence measuring instrument}

In the construct validity test of benevolence variables, researchers conducted a validity test with the CFA first order model. In this study, the construct of the benevolence variable is unidimensional. The calculation of CFA data for the one factor model of this variable obtained the initial calculation score Chi-Square $=$ I7.64, $\mathrm{df}=5$, P-Value $=0.00343$, and RMSEA $=0.101$. With a P-Value $0.00343(<0.05)$ which means that this model is not yet fit. Then the researchers made modifications to this model, namely by freeing each item to 
correlate. After one modification, the Chi-Square value $=6.74, \mathrm{df}=4, \mathrm{P}-\mathrm{Value}=0.1502 \mathrm{I}$, and RMSEA $=$ 0.052. With a P-Value $>0.05$ it means that this model is fit. Thus the items in this benevolence variable only measure one factor, namely benevolence.

The next step is to look at whether or not the item is significant in measuring what is being measured, as well as determining whether a particular item needs to be dropped or not. In this case, what is tested is the factor load coefficient of the item. The test is done by looking at the T-value for each factor load coefficient, if the T-value $>I .96$ means that the item is significant and vice versa. The factor load coefficient for benevolence measurement items is presented in table IO.

Table I0. Loading Factor of Benevolence

\begin{tabular}{lllll}
\hline Item & Coefficient & Standard Error & T-value & Significant \\
\hline I5 & 0.47 & 0.07 & 6.34 & $\sqrt{ }$ \\
28 & 0.47 & 0.08 & 5.74 & $\sqrt{ }$ \\
29 & 0.63 & 0.08 & 7.79 & $\sqrt{ }$ \\
33 & 0.71 & 0.08 & 8.52 & $\sqrt{ }$ \\
45 & 0.25 & 0.08 & 3.24 & $\sqrt{ }$ \\
\hline
\end{tabular}

Note: the sign $\sqrt{ }=$ significant ( $\mathrm{t}>$ I.96); $\mathrm{X}=$ not significant

Based on table I0, it can be seen that all items are significant ( $>$ I.96) and all coefficients are positively charged. This means that the five items in the benevolence measuring instrument prove to be significant and will not be dropped, and can be included in the analysis of the hypothesis test.

\section{Test the validity of universalism measuring instrument}

In the test of construct validity of universalism variables, researchers conducted validity tests with the first order CFA model. In this study, the construct of the universalism variable is unidimensional. Calculation of the CFA data for the one factor model of this variable obtained the initial calculation score Chi-Square = 4I.57, $\mathrm{df}=5$, P-Value $=0.00000$, and RMSEA $=0.17 \mathrm{I}$. With a P-Value of $0.00000(<0.05)$ which means that this model is not yet fit. Then the researchers made modifications to this model, namely by freeing each item to correlate. After two modifications, the Chi-Square value $=1.02, \mathrm{df}=3, \mathrm{P}-$ Value $=0.79658$, and RMSEA $=0.000$. With a P-Value $>0.05$ it means that this model is fit. Thus the items in this universalism variable only measure one factor, namely universalism.

The next step is to look at whether or not the item is significant in measuring what is being measured, as well as determining whether a particular item needs to be dropped or not. In this case, what is tested is the factor load coefficient of the item. The test is done by looking at the T-value for each factor load coefficient, if the T-value $>$ I.96 means that the item is significant and vice versa. The factor load coefficient for universalism measurement items is presented in table II.

Table I I. Loading Factor of Universalism

\begin{tabular}{lllll}
\hline Item & Coefficient & Standard Error & T-value & Significant \\
\hline I & 0.35 & 0.08 & 4.61 & $\sqrt{ }$ \\
2 & 0.24 & 0.07 & 3.27 & $\sqrt{ }$ \\
30 & 0.37 & 0.10 & 3.64 & $\sqrt{ }$ \\
35 & 0.80 & 0.10 & 7.66 & $\sqrt{ }$ \\
38 & 0.59 & 0.09 & 6.72 & $\sqrt{ }$ \\
\hline
\end{tabular}

Note: the sign $\sqrt{ }=$ significant ( $\mathrm{t}>$ I.96); $\mathrm{X}=$ not significant

Based on table II, it can be seen that all items are significant ( $\mathrm{t}>\mathrm{I} .96$ ) and all coefficients are positively charged. This means that the five items in the universalism measuring instrument prove to be significant and will not be dropped, and can be included in the analysis of the hypothesis test. 


\section{Discussion}

The results showed that based on data analysis using Confirmatory Factor Analysis (CFA) explained that the Schwartz Value Survey (SVS) is a measuring tool that can be used properly to measure the basic values owned by individuals who in this case are settled foreigner students. The results of this study also show that all dimensions of basic values, namely self-direction, stimulation, hedonism, achievement, power, security, conformity, tradition, benevolence, and universalism, require a brief modification to achieve model fit.

After conducting a factor analysis of the IO dimensions of the basic values variable, it appears that the Schwartz Value Survey (SVS) measuring instrument is still feasible to use, but it is necessary to improve and update items that have quite a lot of multidimensional. In generally, all of the aspect from basic values are fit with the data. The validity test shows that the Schwartz Value Survey (SVS) is a measuring tool that is still used in Indonesia to measure the basic personal values of individuals, who in this case are transmigrant students from outside the area to Jakarta.

Based on the results of the CFA test shows that there is a correlation between measurement error on each item on all dimensions of basic value. This shows that the item measures the thing to be measured, it also measures other things (multidimensional). The test results also show that the Schwartz Value Survey (SVS) is a multidimensional measurement tool. The Schwartz Value Survey (SVS) proves high loading factors and shows better mode fit data. Overall, although the Schwartz Value Survey (SVS) has been accepted as a psychometric measure, in the future it is necessary to compare this measuring instrument with other similar measuring instruments, which measure these basic personal values.

\section{Conclusion}

Based on the explanation of the results in this study, then based on this it can be concluded as follows:

The results showed that all subscales in the Schwartz Value Survey (SVS) fit the data. This measuring instrument is multidimensional, meaning that it can measure more than one thing that is defined on the subscale. Based on the results of the first order CFA on the measuring instrument there are 50 items that are fit to measure the basic value, with IO dimensions used.

As a suggestion in this study, In future studies, it is expected to develop well and thoroughly on each item used, especially if the item is the result of adaptation from foreign research. Apart from that, the committee is expected to be able to use measuring devices whose number of items does not correlate too much, or measurement errors and have unidimensional nature, meaning that the item really examines one dimension in focus.

Suggest for the next a kind researchs about measurement instrument Schwartz Value Survey (SVS), better if with additional analysis to show interrelationship between the dimensions (IO factors) and posibility to find more generally dimensions. And expected to the next research makes to advance analysis use Exploratory Factor Analysis (EFA).

\section{References}

Allen, M.J. \& Yen, W.M. (1979).Introduction to measurement theory. Monterey: Brooks Cole.

Anastasi, A. Dan Urbina, U., 1997, Psychological testing (seventh edition), Prentice- allinc, New Jersey.

Bardi, A., \& Schwartz. S. H. (2003). Values and behavior: Strength and structure of relations. Society for Personality and Social Psychology.Inc, 29 (10), I207-I220.

Bilsky, W., \& Schwartz, S.H. (1994). Values and personality. European Journal of Personality, 8, I63-I8I. 
Bollen, K. A. (1989). Structural equations with latent variables. New York, NY: John Wiley \& Sons, Inc.

Borualogo, I. S. (20I4). Pengaruh nilai budaya merantau, sistem nilai, dan dukungan sosial yang dimediasi harga diri terhadap kepegasan sebagai penentu kepuasan hidup. Disertasi (Non Publikasi.) Bandung: Universitas Padjajaran.

Brown, A Timothy. (2006). Confirmatory factor analysis for research. New York: The Guilford Press.

Cutrona, C. E., \& Russel, D. W. (1987). The provision of social relationship and adaptation to stress. Advanced in Personal Relationship, I, 37-67.

Fischer, R., \& Schwartz, S. H. (20II). Whence differences in value priorities?: Individual, cultural or artifactual sources. Journal of Cross-Cultural Psychology, 42 (7), I I27-I I 44.

Fox, Jean-Paul. (2010). Bayesian item response modeling: Theory and applications. New York: Springer.

Grunert, S. C., \& Juhl, H. J. (1995). Values, environmental attitudes and buying of organic foods. Journal of Economic Psychology, 16, 39-62.

Heck, H. R., \& Thomas, L. S. 2005. An introduction to multilevel modeling techniques. New York: Routledge Taylor \&Prancis Group

Kaplan, R. M. \&Saccuzzo. (2005). Psychological Testing: principles, application, and issues (6th ed.). Belmont : Thomson Wadsworth.

Lee, S. Y. (2007). Structural equation modeling: a bayesian approach.Chicester: John Wiley \& Sons Ltd.

Misra, R., Crist, M., \&Burant, C. J. (2003). Relationships among life stress, social support, academic stressors, and reactions to stressors of international students in the United States. Educational Publishing Foundation, IO (2), I37-I57.

Mugan, R. F. (2005).A response to the psychological and physical health risks of international college students studying in the united states: an integrative program proposal. Dissertation. University of Hartford.

Muthen, B. O. 1989. Latent variable modeling in heterogenous populations.Psychometrika, 54, No. 4, 557585.

Nosse, L. J., \& Sagiv, L. (2005). Theory-based study of the basic values of 565 physical therapists. Physical Therapy, 85, 834-850.

Oebadillah, S. (2015).Peringkat II PTN TerbaikVersiKemristekdikti.Diunduhpadatanggal I3 Oktober 20I5, pukul I8:52 WIB dari http://news.metrotvnews.com/read/20I5/08/I8/422235/peringkatII-ptn-terbaik-versi-kemristekdikti.

Ros, M., Schwartz, S. H., \& Surkiss, S. (I999). Basic individual values, work values, and the meanging of work. International Association of Applied Psychology, 48, 49-7I.

Schwartz, S. H. (2005).Basic human values: An overview. Basic human values: Theory, methods, and applications. The Hebrew University of Jerusalem, http://151.97.II0.134/Allegati/convegno\%2078-10-05/Schwartzpaper.pdf. accessed on I0 Nov 2014.

Schwartz, S. H. (2012). An overview of the Schwartz theory of basic values. International Association for Cross-Cultural Psychology, 2 (I). doi.org/10.9707/2307-0919.1II6.

Schwartz, S.H. (1992). Universal in the content and structure of value: Theoriticaladvances and empiricaltests in 20 countries. Journal of Advances in Experimental Social Psychology, 25, I-65. 
Schwartz, S.H. (1994). Are there universal aspect in the structure \& contents of human values?.Journal of Social Issues, 50 (4), I9-45.

Spini, D. (2003). Measurement equivalence of 10 value types from the schwartz value survey across 21 countries. Journal of Cross-Cultural Psychology, 34 (I), 3-23.

Sugiyono. (20I I). Metode penelitian kuantitatif kualitatif dan $R$ \& D. Bandung: Alfabeta, CV.

Umar, J. (2012). Confirmatory factor analysis. Bahan ajar perkuliahan. Fakultas Psikologi UIN Jakarta. 